\title{
Hypophysectomy of Coho Salmon (Oncorhynchus kisutch) and Survival in Fresh Water and Seawater
}

\author{
RICHARD S. NISHIOKA ${ }^{1}$, N. HAROLD RICHMAN, III ${ }^{1,3}$, GRAHAM YOUNG ${ }^{1}$, PATRICK \\ PRUNET $^{1,2}$ and HOWARD A. BERN ${ }^{1}$ \\ ${ }^{1}$ Department of Zoology and Cancer Research Laboratory, University of California, Berkeley, \\ CA 94720 (U.S.A.) \\ ${ }^{2}$ Laboratory of Fish Physiology, I.N.R.A., Campus de Beaulieu, Rennes (France) \\ ${ }^{3}$ Present address: Department of Zoology and Hawaii Institute of Marine Biology, University of \\ Hawaii, Honolulu, HI 96822 (U.S.A.)
}

(Accepted 1 April 1987)

\begin{abstract}
Nishioka, R. S., Richman, N. H., III, Young, G., Prunet, P. and Bern, H. A., 1987. Hypophysectomy of coho salmon (Oncorhynchus kisutch) and survival in fresh water and seawater. Aquaculture, 65: 343-352.
\end{abstract}

Coho salmon were hypophysectomized by a transorbital surgical technique. Hypophysectomized coho survived in fresh water but not in seawater. Plasma sodium levels were lower in hypophysectomized fish in fresh water and in 1/4 (isotonic) seawater than in sham-operated fish, suggesting impaired osmoregulatory function in hypophysectomized fish. In addition, $\mathrm{Na}^{+}, \mathrm{K}^{+}$-ATPase activity was reduced in hypophysectomized freshwater fish.

\section{INTRODUCTION}

Anadromous salmonids undergo smoltification which, among other changes, results in a preadaptive enhancement of hypoosmoregulatory ability prior to migration into the ocean. Despite the substantial advances that have been made over the past decade in our understanding of the endocrine control of this transformation (cf. Hoar, 1976; Barron, 1986), little is known about the endocrinology of salmonid osmoregulatory processes. From the few studies that have been made using hypophysectomized fish from the genus Salmo, it is already apparent that the classical picture derived from euryhaline species of higher orders of teleosts generally showing prolactin as mandatory for the maintenance of hydromineral balance in hypoosmotic environments cannot necessarily be applied to salmonids, since hypophysectomized Atlantic salmon, Salmo salar, and rainbow trout, $S$. gairdneri, survive in fresh water with little 
reduction in plasma $\mathrm{Na}^{+}$(Donaldson and McBride, 1967; Komourdjian and Idler, 1977; Björnsson and Hansson, 1983; Komourdjian, 1984). Additionally, mounting evidence suggests that growth hormone may function as a seawateradapting hormone in salmonids (see Bolton et al., 1987), whereas cortisol is considered to be the seawater-adapting hormone in other euryhaline teleosts.

Hypophysectomy is critical for the analysis of pituitary control over hydromineral regulation. The lack of a suitable technique for pituitary ablation in species of the genus Oncorhynchus has limited previous endocrine studies to intact fish (e.g., Redding et al., 1984; Richman and Zaugg, 1987) with the exception of two recent studies on hypophysectomy of coho salmon, $O$. kisutch (Iwata et al., 1987; Richman et al., 1987a), which utilized the technique described herein. The present paper describes in detail a technique for hypophysectomy of coho salmon and includes results of preliminary investigations on osmoregulation in hypophysectomized animals.

\section{MATERIALS AND METHODS}

\section{Animals}

Coho salmon (Oncorhynchus kisutch) used in this study were obtained from Iron Gate or Trinity River Hatchery (California Department of Fish and Game) and held at the Bodega Marine Laboratory in outdoor recirculating freshwater (FW) raceways (natural photoperiod and temperature). Groups of fish 15-22 months old to be used in hypophysectomy experiments were transported to Berkeley and allowed to acclimate in outdoor (natural photoperiod ), temperature-controlled $\left(14 \pm 2^{\circ} \mathrm{C}\right), 150$-gallon circular or rectangular tanks. Fish averaging $25-85 \mathrm{~g}$, optimal in size for hypophysectomy, were acclimated at least 2 weeks prior to the start of an experiment and were allowed to recover postoperatively for at least 1 week in $1 / 4(6-8 \% 0)$ artificial seawater (SW) (Marine Environment, San Francisco, CA). Experiments were conducted in either 25- or 45-gallon tanks in temperature-controlled rooms $\left(14 \pm 1{ }^{\circ} \mathrm{C} ; 12 \mathrm{~L}: 12 \mathrm{D}\right)$ or in outdoor tanks similar to the acclimation tanks.

\section{Hypophysectomy}

Coho were hypophysectomized $(\mathrm{Hx})$ using the transorbital surgical technique originally developed for the tilapia (Oreochromis mossambicus; formerly Sarotherodon mossambicus) by Nishioka (1980). Freshwater coho salmon were anesthetized with $0.1 \mathrm{~g} / \mathrm{l}$ ethyl $m$-aminobenzoate (MS-222; Sigma, St. Louis, $\mathrm{MO}$ ), buffered with $0.075 \mathrm{~g} / \mathrm{l}$ potassium carbonate or sodium bicarbonate in isotonic $1 / 4 \mathrm{SW}$. Each animal was placed on its left side in a shallow V-shaped plexiglass perfusion trough and kept cool and damp with a moistened paper towel. The buccal cavity was perfused with ice-chilled anesthetic solution 
diluted to approximately $50 \%$ with $1 / 4 \mathrm{SW}$ to maintain anesthesia and to obtain slow, shallow opercular movement. After cutting the conjunctiva around the right eye, the eye was removed by severing the optic nerve and ocular muscles.

Excess fatty tissue and blood were removed using cotton-tipped swabs to clear the surgical field. Bleeding from the large ophthalmic and other smaller optic arteries was arrested using a hyfrecator (Birtcher, Los Angeles, CA). A hole was drilled with a \# 5 carbide burr (S.S. White Dental Products, Philadelphia, PA) through the orbitosphenoid bone between the orbital artery and the optic foramen. The area caudodorsal to the optic foramen is free of major blood vessels. A Pasteur pipette with a tip drawn to match the diameter of the pituitary and bent to form an arc was inserted through the hole and positioned over the pituitary (which remains hidden from view), using landmarks such as parts of the optic chiasma visible through the cranium. Gentle oral suction was used to remove the pituitary. After examination of the pituitary to verify complete ablation, the hole was sealed with avitene, a microfibrillar collagen hemostat (Alcon Laboratories, Fort Worth, TX), and the animal was returned to fresh 1/4 SW for recovery. Sham-operated (SO) control animals were treated identically except for pipette insertion and pituitary aspiration.

The operation required $10-15$ min to perform and both $\mathrm{Hx}$ and SO controls recovered from anesthesia within a few minutes following transfer to fresh $1 / 4$ SW. All operated fish were held for at least 1 week of postoperative recovery in 1/4 SW containing the antibiotic Maracyn (Mardel Laboratories, Villa Park, IL). After initial revival following surgery, survival during the 1-week recovery period was good, about $70 \%$ for $\mathrm{Hx}$ fish and $>95 \%$ for SO controls. Among the $\mathrm{Hx}$ fish that died during the recovery period were some that had bled considerably and others in which parts of the hypothalamus had been inadvertently removed in addition to the pituitary.

At the end of each experiment, the hypothalamic area of the brain and the hypophysial fossa were visually inspected by removing the top of the cranium and reflecting the brain anteriorly. Fish in the hypophysectomized group with pituitary fragments were eliminated from the study. Pituitary fragments stood out clearly in the clotted blood. Postmortem examinations showed that the operation was successful in more than $80 \%$ of the $\mathrm{Hx}$ fish.

\section{Plasma sodium analysis}

The animals were stunned by concussion and blood was collected from the severed caudal vasculature in microhematocrit capillary tubes coated with ammonium heparinate (Dade; American Scientific Products, McGaw Park, IL). Following centrifugation, blood plasma was stored in polyethylene vials at $-20^{\circ} \mathrm{C}$ until assayed. Samples were prepared by diluting 2 or $4 \mu \mathrm{l}$ of plasma in $10 \mathrm{ml}$ distilled water. Sodium content was determined on duplicate samples with an atomic absorption spectrophotometer (Perkin Elmer, model 290 or 
290B, Mountain View, CA). Sodium standards, prepared from oven-dried sodium chloride in distilled water, were used to prepare standard curves and for determining plasma sodium levels.

Gill $\mathrm{Na}^{+}, \mathrm{K}^{+}$-ATPase analysis

Gill filaments from six to eight gill arches were collected from each animal for enzyme analysis. The filaments were dissected from the arches and placed in homogenizing medium ( $0.3 \mathrm{M}$ sucrose, $0.02 \mathrm{M}$ EDTA, $0.1 \mathrm{M}$ imidazole). Samples were frozen immediately on dry ice and maintained at $-80^{\circ} \mathrm{C}$ until assayed. Enzyme activity was determined by W. Zaugg using his standard method (Zaugg, 1982).

\section{Plasma cortisol and prolactin radioimmunoassays (RIA)}

Blood was collected as described for sodium analysis on the same fish. Cortisol in the plasma was assayed using the direct assay technique of Redding et al. (1984) after validation (Young, 1986). Plasma samples (20- $\mu$ l aliquots) were assayed without prior extraction but after denaturation of binding proteins by heat treatment $\left(100^{\circ} \mathrm{C}\right.$ for $\left.15 \mathrm{~min}\right)$. Cortisol was determined from standard curves with a radioimmunoassay program (HP41-CV; HewlettPackard, Corvallis, OR). The assay sensitivity was $1.0 \mathrm{ng} / \mathrm{ml}$. Plasma prolactin was radioimmunoassayed as described by Prunet et al. (1985); see also Hirano et al. (1985).

\section{Statistical analysis}

Student's $t$-test (assuming equal variances) was used for statistical comparisons between two groups. The calculations were performed with a $t$-test program from Hewlett-Packard.

\section{Experimental protocol}

The first experiment (I - early April to mid-May 1984) examined the effects of hypophysectomy on FW tolerance and gill enzyme activity. $\mathrm{SO}$ and $\mathrm{Hx}$ smolts were transferred directly to FW (dechlorinated tapwater of low mineral content). The fish were held for 1 month in FW which was renewed periodically. The experiment was then terminated, and gill and plasma samples were collected for analysis.

The second experiment (IIa - mid-November to early December 1984) examined the effects of hypophysectomy on SW tolerance. $\mathrm{Hx}$ and SO fish (7-8/group), were transferred to FW for 1 week, then to SW ( $30 \%$ ) for $48 \mathrm{~h}$, and plasma samples were collected. Concurrently, $\mathrm{Hx}$ and SO fish (4 and 9 , 
TABLE 1

Plasma cortisol, prolactin and gill $\mathrm{Na}^{+}, \mathrm{K}^{+}$-ATPase activity in hypophysectomized ( $\mathrm{Hx}$ ) and sham-operated (SO) coho salmon held in fresh water for 1 month. Values are mean \pm SE with $n$ in parentheses. ND denotes values which were non-detectable $(<1.0 \mathrm{ng} / \mathrm{ml})$

\begin{tabular}{llll}
\hline Animal & $\begin{array}{l}\text { Cortisol } \\
(\mathrm{ng} / \mathrm{ml})\end{array}$ & $\begin{array}{l}\text { Prolactin } \\
(\mathrm{ng} / \mathrm{ml})\end{array}$ & $\begin{array}{l}\mathrm{Na}^{+}, \mathrm{K}^{+} \text {-ATPase } \\
\left(\mu \text { moles Pi mg protein }{ }^{-1} \mathrm{~h}^{-1}\right)\end{array}$ \\
\hline SO & $15.3 \pm 6.8(7)$ & $3.56 \pm 0.38(7)$ & $13.9 \pm 1.4(6)$ \\
$\mathrm{Hx}$ & $\mathrm{ND}(7)$ & $2.16 \pm 0.20(7)^{*}$ & $6.9 \pm 0.4(7)^{*}$ \\
\hline
\end{tabular}

*Significantly different $(P<0.05)$ from sham-operated controls.

respectively), were retained in $1 / 4 \mathrm{SW}$. Owing to high mortality in the $\mathrm{Hx}$ group in SW, the experiment was repeated later. In this experiment (IIb-early April to early May 1985), an additional unoperated control group was included and the intermediate FW transfer step was omitted. At the start of the experiment groups of $\mathrm{Hx}, \mathrm{SO}$, and intact fish were each divided into three subgroups (7-8/subgroup) and transferred from $1 / 4 \mathrm{SW}$ to $\mathrm{FW}, \mathrm{SW}$, or fresh $1 / 4 \mathrm{SW}$. The experiment was terminated after 15 days and plasma samples were collected.

\section{RESULTS}

As an indicator of successful hypophysectomy, plasma cortisol levels were determined in the animals from the first experiment (FW transfer). Cortisol was non-detectable in the plasma from $\mathrm{Hx}$ coho, but was present in $\mathrm{SO}$ control plasma (Table 1). Prolactin levels were significantly reduced $(P<0.05)$ by hypophysectomy; however, levels remained detectable by RIA despite complete removal of the hypophysis.

Mortality in $\mathrm{Hx}$ coho was much greater in SW than in FW (Table 2).

\section{TABLE 2}

Mortality in different salinities of hypophysectomized ( $\mathrm{Hx}$ ) and sham-operated (SO) coho salmon after at least 1 week following surgery. Values are number of mortalities over total number of animals transferred

\begin{tabular}{lrrrl}
\hline Expt. & Salinity & SO & Hx & Intact \\
\hline I & FW & $0 / 7$ & $0 / 7$ & - \\
IIa & $1 / 4$ SW & $0 / 9$ & $0 / 4$ & - \\
& SW & $1 / 7$ & $5 / 8$ & - \\
IIb & FW & $0 / 8$ & $2 / 7$ & $0 / 8$ \\
& $1 / 4$ SW & $0 / 8$ & $3 / 8$ & $0 / 8$ \\
& SW & $0 / 8$ & $8 / 8$ & $1 / 8$ \\
\hline
\end{tabular}


TABLE 3

Plasma sodium levels of hypophysectomized $(\mathrm{Hx})$ and sham-operated (SO) coho salmon from different salinities. Values are mean $\pm S E$ with $n$ in parentheses

\begin{tabular}{lrll}
\hline Expt. & Salinity & SO $(\mathrm{m} M)$ & $\mathrm{Hx}(\mathrm{m} M)$ \\
\hline I & FW & $152.4 \pm 1.7(7)$ & $147.5 \pm 1.7(7)^{*}$ \\
II & $1 / 4 \mathrm{SW}$ & $154.6 \pm 0.9(8)$ & $148.5 \pm 1.3(4)^{*}$ \\
& SW & $191.5 \pm 2.8(6)$ & $202.7 \pm 8.2(3)$
\end{tabular}

*Significantly different $(P<0.05)$ from SO animals.

Whereas $\mathrm{Hx}$ animals in the first experiment survived for the duration of the experiment (1 month) in FW, the $\mathrm{Hx}$ animals which were held 1 week in $\mathrm{FW}$ and then transferred to SW (Experiment IIa) began to die after about $12 \mathrm{~h}$ in SW. Five out of eight animals died within $48 \mathrm{~h}$ after transfer. The three surviving fish appeared stressed. In contrast, the group which remained in $1 / 4 \mathrm{SW}$ did not suffer any mortality and behaved normally. All $\mathrm{Hx}$ animals transferred from isotonic (1/4) SW to SW (Experiment IIb) died within $96 \mathrm{~h}$. Mortalities in the other transferred groups ( $\mathrm{Hx}$ and controls) were low and occurred after 4 days.

Hypophysectomy impaired the osmoregulatory capability of coho salmon. Plasma sodium concentrations in FW $\mathrm{Hx}$ animals were significantly lower ( $P<0.05$, one-tail comparison) than in SO controls (Table 3 ). Similar results were obtained from animals maintained in $1 / 4 \mathrm{SW}$. Furthermore, hypophysectomy caused a significant $(P<0.05)$ reduction in gill $\mathrm{Na}^{+}, \mathrm{K}^{+}$-ATPase activity in FW animals (Table 1). Plasma sodium levels, although higher in the surviving $\mathrm{Hx}$ animals in SW, did not differ significantly from SO controls possibly owing to greater variability of the sodium levels. Some survival and moderate plasma sodium levels, despite complete hypophysectomy, may be due to the variability in time required to reach lethal levels of ionic imbalance.

A few days after hypophysectomy the fish in $1 / 4 \mathrm{SW}$ (isotonic) turned metallic grayish regardless of the color of the background. When fish were transferred to $100 \% \mathrm{SW}$, the darkening intensified prior to death.

\section{DISCUSSION}

The transorbital surgical technique for hypophysectomy has been successfully adapted to coho salmon. This method is particularly well suited for the hypophysectomy of coho and other fish wherein a high keel of the parasphenoid bone to which many pharyngeal and other muscles attach makes hypophysectomy through the oral approach difficult. This surgical procedure is relatively rapid, taking 10-15 min to perform, and about $70 \%$ of the fish survive the operation and the subsequent recovery period. In most cases, the pituitary was 
removed intact thereby permitting an immediate evaluation of the operation. Although the operation is similar to the method described for tilapia (Nishioka, 1980 ), some modifications were necessary. Coho required continual irrigation of the gills with aerated water, unlike tilapia. Enucleation usually caused extensive bleeding from the ophthalmic artery, which necessitated cauterization.

In most cases the integument of $\mathrm{Hx}$ coho tended to appear mottled or grayish to dusky with an underlying bluish cast regardless of the color of the tank. The darker coloration was accentuated in animals after transfer to SW. Integumentary color change has been described in other teleost species after hypophysectomy (e.g., Chavin, 1956; Sundararaj and Goswami, 1965; Yamazaki, 1976; Komourdjian and Idler, 1977; Komourdjian, 1984). This darkening, although variable in most studies, was sufficiently consistent in Heteropneustes fossilis and Salmo salar to be useful as an indicator of the success of pituitary ablation (Sundararaj and Goswami, 1965; Komourdjian, 1984). The variability of darkening among different species may reflect the different degrees of neural and endocrine control over coloration. Neural control was evident in $\mathrm{Hx}$ goldfish where dark background colors induced darker integumentary coloration (Chavin, 1956).

Plasma cortisol levels, measurable in SO coho, were non-detectable $(<1.0$ $\mathrm{ng} / \mathrm{ml}$ ) in Hx animals (cf. Richman et al., 1987a). Reduced levels of cortisol have been observed after $\mathrm{Hx}$ in S. gairdneri (Donaldson and McBride, 1967), A. anguilla (Hirano, 1969), H. fossilis (Parwez et al., 1984) and Carassius auratus (Porthe-Nibelle and Lahlou, 1974). Inasmuch as cortisol secretion is dependent on pituitary adrenocorticotropin, these data would indicate successful pituitary ablation. The cortisol levels in SO animals are higher than the basal (unstressed) levels reported elsewhere (cf. Barton et al., 1985; Young, 1986 ). These high levels almost certainly result from the stress of netting and handling the animals.

For unknown reasons, the PRL levels, although reduced significantly by hypophysectomy, remained detectable. Inasmuch as the specificity of this RIA has been reported for salmonids (Hirano et al., 1985; Prunet et al., 1985), the possible existence of an extrapituitary source of PRL cannot be dismissed.

In general, $\mathrm{Hx}$ teleosts unable to survive in $\mathrm{FW}$ or seawater ( $\mathrm{SW}$ ) for long periods exhibit signs of osmoregulatory failure usually measured as altered plasma electrolyte levels. The nature of osmoregulatory failure in $\mathrm{Hx}$ teleosts is variable and results from the impairment of one or more ion- and watertransporting epithelia.

Hypophysectomized coho, like hypophysectomized rainbow trout ( $S$. gairdneri) (Donaldson and McBride, 1967; Björnsson and Hansson, 1983) and Atlantic salmon ( $S$. salar) (Komourdjian and Idler, 1977; Komourdjian, 1984), were able to survive in FW but not in SW. In contrast, $\mathrm{Hx}$ brown trout ( $S$. trutta) survived in $75 \% \mathrm{SW}$ but not in FW (Oduleye, 1976). Although coho 
survived in FW, the modest drop in plasma sodium levels indicates that osmoregulatory mechanisms were somewhat impaired by hypophysectomy. Similarly, declines in plasma electrolytes have been reported for other $\mathrm{Hx}$ salmonid species (Komourdjian and Idler, 1977; Björnsson and Hansson, 1983; Komourdjian, 1984). After an initial loss, however, Komourdjian (1984) observed a partial restoration of plasma sodium in freshwater Hx Atlantic salmon and concluded that these animals were osmoregulating despite hypophysectomy. The modest decline in plasma sodium levels in $\mathrm{Hx}$ coho after 1 month in FW suggests that the response of coho to hypophysectomy may be similar to that in Atlantic salmon.

In the absence of the pituitary, coho gill $\mathrm{Na}^{+}, \mathrm{K}^{+}$-ATPase activity, as in other teleosts (Epstein et al., 1967; Pickford et al., 1970; Milne et al., 1971), was significantly reduced. In contrast to the FW-adapted coho, the loss of enzyme activity in other species occurred in SW-adapted animals where enzyme activity is normally high. However, during smoltification of coho (early spring in California), the period in which part of this study was conducted, gill $\mathrm{Na}^{+}$, $\mathrm{K}^{+}$-ATPase activity in FW salmon is normally elevated in preparation for ocean life (Zaugg and McLain, 1970, 1972; Richman and Zaugg, 1987; Richman et al., 1987b). The $\mathrm{Na}^{+}, \mathrm{K}^{+}$-ATPase values of the SO fish in this study are lower in comparison with those reported by Richman and Zaugg (1987) in intact fish. This difference may be attributable to several factors including the surgical stress of eye removal, differences in holding facilities or the stage of smoltification. Nevertheless, these results suggest that the normal smoltification-associated increase in gill $\mathrm{Na}^{+}, \mathrm{K}^{+}$-ATPase activity is pituitarydependent.

\section{ACKNOWLEDGMENTS}

We wish to express our appreciation to Dr. W. Zaugg for the analysis of gill $\mathrm{Na}^{+}, \mathrm{K}^{+}$-ATPase activity reported in this study. We are grateful to J. Underhill and K.T. Mills for their excellent technical support, and to the hatchery personnel of the California Department of Fish and Game for their cooperation. This study was supported in part by NOAA, National Sea Grant College Program, Department of Commerce, under grant number NA80AA-D-00120, through the California Sea Grant College Program, and in part by the California State Resources Agency Project numbers R/F-78 and R/F-101, by NSF grant PCM 84-05249, and by funds from NATO (to P.P.). The U.S. Government is authorized to produce and distribute reprints for governmental purposes.

\section{REFERENCES}

Barron, M. G., 1986. Endocrine control of smoltification in anadromous salmonids. J. Endocrinol., 108: 313-319. 
Barton, B. A., Schreck, C. B., Ewing, R. D., Hemmingsen, A. R. and Patino, R., 1985. Changes in plasma cortisol during stress and smoltification in coho salmon, Oncorhynchus kisutch. Gen. Comp. Endocrinol., 59: 468-471.

Björnsson, B. Th. and Hansson, T., 1983. Effects of hypophysectomy on the plasma ionic and osmotic balance in rainbow trout, Salmo gairdneri. Gen. Comp. Endocrinol., 49: 240-247.

Bolton, J. P., Collie, N. L., Kawauchi, H. and Hirano, T., 1987. Osmoregulatory actions of growth hormone in rainbow trout (Salmo gairdneri). J. Endocrinol., 112: 63-68.

Chavin, W., 1956. Pituitary-adrenal control of melanization in xanthic goldfish (Carassius aura tus L.). J. Exp. Zool., 133: 1-46.

Donaldson, E. M. and McBride, J. R., 1967. The effects of hypophysectomy in the rainbow trout Salmo gairdnerii (Rich.) with special reference to the pituitary-interrenal axis. Gen. Comp. Endocrinol., 9: 93-101.

Epstein, F. H., Katz, A. I. and Pickford, G. E., 1967. Sodium- and potassium-activated adenosine triphosphatase of gills: role in adaptation of teleosts to salt water. Science, 156: 1245-1247.

Hirano, T., 1969. Effects of hypophysectomy and salinity change on plasma cortisol concentration in the Japanese eel, Anguilla japonica. Endocrinol. Jpn., 16: 557-560.

Hirano, T., Prunet, P., Kawauchi, H., Takahashi, A., Ogasawara, T., Kubota, J., Nishioka, R.S., Bern, H. A., 'Takada, K. and Ishii, S., 1985. Development and validation of a salmon prolactin radioimmunoassay. Gen. Comp. Endocrinol., 59: 266-276.

Hoar, W. S., 1976. Smolt transformation: evolution, behavior and physiology. J. Fish. Res. Board Can., 33: 1233-1252.

Iwata, M., Nishioka, R. S. and Bern, H. A., 1987. Whole animal transepithelial potential (TEP) of coho salmon during parr-smolt transformation and the effects of thyroxine, prolactin and hypophysectomy. Fish Physiol. Biochem., 3: 25-38.

Komourdjian, M. P., 1984. Monovalent plasma ion regulation in the hypophysectomized Atlantic salmon. Gen. Comp. Endocrinol., 56: 278-282.

Komourdjian, M. P. and Idler, D. R., 1977. Hypophysectomy of rainbow trout, Salmo gairdneri, and its effect on plasmatic sodium regulation. Gen. Comp. Endocrinol., 32: 536-542.

Milne, K. P., Ball, J. N. and Chester Jones, I., 1971. Effects of salinity, hypophysectomy and corticotropin on branchial Na- and K- activated ATPase in the eel, Anguilla anguilla L. J. Endocrinol., 49: 177-178.

Nishioka, R. S., 1980. Hypophysectomy of tilapia (Sarotherodon mossambicus) through the orbit. Gen. Comp. Endocrinol., 40: 377-378.

Oduleye, S. O., 1976. The effects of hypophysectomy, prolactin therapy and environmental calcium on freshwater survival and salinity tolerance in the brown trout Salmo trutta L. J. Fish Biol., 9; 463-470.

Parwez, I., Goswami, S. V. and Sundararaj, B. I., 1984. Effects of hypophysectomy on some osmoregulatory parameters of the catfish, Heteropneustes fossilis (Bloch). J. Exp. Zool., 229: 375-381.

Pickford, G. E., Pang, P. K. T., Weinstein, E., Torretti, J. Hendler, E. and Epstein, F. H., 1970. The response of the hypophysectomized cyprinodont, Fundulus heteroclitus, to replacement therapy with cortisol: effects on blood serum and sodium-potassium activated adenosine triphosphatase in the gills, kidney, and intestinal mucosa. Gen. Comp. Endocrinol., 14: 524-534.

Porthe-Nibelle, J. and Lahlou, B., 1974. Plasma concentrations of cortisol in hypophysectomized and sodium chloride-adapted goldfish (Carassius auratus L.). J. Endocrinol., 63: 377-387.

Prunet, P., Boeuf, G. and Houdebine, L. M., 1985. Plasma and pituitary prolactin levels in rainbow trout during adaptation to different salinities. J. Exp. Zool., 235: 187-196.

Redding, J. M., Schreck, C. B., Birks, E. K. and Ewing, R. D., 1984. Cortisol and its effects on plasma thyroid hormone and electrolyte concentrations in fresh water and during seawater acclimation in yearling coho salmon, Oncorhynchus kisutch. Gen. Comp. Endocrinol., 56: 146-155.

Richman, N. H. III, Nishioka, R. S., Young, G. and Bern, H. A., 1987a. Effects of cortisol and 
growth hormone replacement on osmoregulation in hypophysectomized coho salmon (Oncorhynchus kisutch). Gen. Comp. Endocrinol., in press.

Richman, N. H. III, Tai de Diaz, S., Nishioka, R. S., Prunet, P. and Bern, H. A., 1987b. Osmoregulatory and endocrine relationships with chloride cell morphology and density during smoltification in coho salmon (Oncorhynchus kisutch). Aquaculture, 60: 265-285.

Richman, N. H. III and Zaugg, W. S., 1987. Effects of cortisol and growth hormone on osmoregulation in pre- and post-smoltified coho salmon (Oncorhynchus kisutch). Gen. Comp. Endocrinol., 65: 189-198.

Sundararaj, B. I. and Goswami, S. V., 1965. 'Seminal vesicle' response of intact, castrate, and hypophysectomized catfish, Heteropneustes fossilis (Bloch), to testosterone propionate, prolactin, and growth hormone. Gen. Comp. Endocrinol., 5: 464-474.

Yamazaki, F. 1976. Applications of hormones in fish culture. J. Fish. Res. Board Can., 33: 948-958.

Young, G., 1986. Cortisol secretion in vitro by the interrenal of coho salmon (Oncorhynchus kisutch) during smoltification: relationship with plasma thyroxine and plasma cortisol. Gen. Comp. Endocrinol., 63: 191-200.

Zaugg, W. S., 1982. A simplified preparation for adenosine triphosphatase determination in gill tissue. Can. J. Fish. Aquat. Sci., 39: 215-217.

Zaugg, W. S. and McLain, L. R., 1970. Adenosinetriphosphatase activity in gills of salmonids: seasonal variations and salt water influence in coho salmon, Oncorhynchus kisutch. Comp. Biochem. Physiol., 35: 587-596.

Zaugg, W.S. and McLain, L. R., 1972. Changes in gill adenosinetriphosphatase activity associated with parr-smolt transformation in steelhead trout, coho, and spring chinook salmon. J. Fish. Res. Board Can., 29: 167-171. 